San Jose State University

SJSU ScholarWorks

Faculty Publications, Biological Sciences

Biological Sciences

$1-1-2011$

\title{
Ecological strategies in California chaparral: Interacting effects of soils, climate, and fire on specific leaf area
}

\author{
B L. Anacker \\ University of California - Davis \\ N Rajakaruna \\ San Jose State University, nrajakaruna@gmail.com \\ D D. Ackerly \\ University of California - Berkeley \\ S P. Harrison \\ University of California - Berkeley \\ J E. Keeley \\ University of California - Davis
}

See next page for additional authors

Follow this and additional works at: https://scholarworks.sjsu.edu/biol_pub

Part of the Plant Sciences Commons

\section{Recommended Citation}

B L. Anacker, N Rajakaruna, D D. Ackerly, S P. Harrison, J E. Keeley, and M C. Vasey. "Ecological strategies in California chaparral: Interacting effects of soils, climate, and fire on specific leaf area" Plant Ecology and Diversity (2011): 179-188. https://doi.org/10.1080/17550874.2011.633573

This Article is brought to you for free and open access by the Biological Sciences at SJSU ScholarWorks. It has been accepted for inclusion in Faculty Publications, Biological Sciences by an authorized administrator of SJSU ScholarWorks. For more information, please contact scholarworks@sjsu.edu. 


\section{Authors}

B L. Anacker, N Rajakaruna, D D. Ackerly, S P. Harrison, J E. Keeley, and M C. Vasey 


\title{
Ecological strategies in California chaparral: interacting effects of soils, climate, and fire on specific leaf area
}

\author{
Brian Anacker ${ }^{*}$, Nishanta Rajakaruna ${ }^{b}$, David Ackerlyc ${ }^{c}$, Susan Harrison ${ }^{\text {, }}$, Jon Keeley ${ }^{\mathrm{e}}$ and Michael Vasey ${ }^{\mathrm{f}}$ \\ ${ }^{a}$ University of California, Davis, Davis, USA; ${ }^{b}$ College of the Atlantic, 105 Eden Street, Bar Harbor, USA; ${ }^{c}$ University of California, \\ 5 Berkeley, Integrative Biology, Berkeley, USA; ${ }^{d}$ University of California, Davis, Environmental Science and Policy, Davis, USA; ${ }^{e}$ US

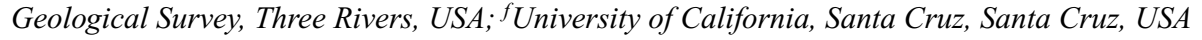

(Received 29 June 2011; final version received 16 October 2011)

\begin{abstract}
Background: High values of specific leaf area (SLA) are generally associated with high maximal growth rates in resource-rich conditions, such as mesic climates and fertile soils. However, fire may complicate this relationship since its frequency varies with both climate and soil fertility, and fire frequency selects for regeneration strategies (resprouting versus seeding) that are not independent of resource-acquisition strategies. Shared ancestry is also expected to affect the distribution of resource-use and regeneration traits.

Aims: We examined climate, soil, and fire as drivers of community-level variation in a key functional trait, SLA, in chaparral in California.

Methods: We quantified the phylogenetic, functional, and environmental non-independence of key traits for 87 species in 115 plots.

Results: Among species, SLA was higher in resprouters than seeders, although not after phylogeny correction. Among communities, mean SLA was lower in harsh interior climates, but in these climates it was higher on more fertile soils and on more recently burned sites; in mesic coastal climates, mean SLA was uniformly high despite variation in soil fertility and fire history.

Conclusions: We conclude that because important correlations exist among both species traits and environmental filters, interpreting the functional and phylogenetic structure of communities may require an understanding of complex interactive effects.
\end{abstract}

Keywords: chaparral; climate; fire; sandstone; serpentine; soil; specific leaf area

\section{Introduction}

Environmental conditions limit the range of viable ecological strategies in a community, creating assemblages in which functionally similar species tend to co-occur (Diamond 1975; Weiher and Keddy 2001; Webb et al. 2002; Cavender-Bares et al. 2009). For example, water or nutrient scarcity may select for species with traits conferring low mean and variance in resource acquisition and growth, such as small thick leaves and high below-ground investment (Grubb 1977; Grime 1979; Diaz et al. 1998; Westoby et al. 2002; Westoby and Wright 2006). For continuous resource-acquisition traits, values are typically measured across single environmental gradients, or in two contrasting habitats, with the expectation that the gradient will filter community composition by limiting the range of trait values found at each site (Knops and Reinhart 2000; Ackerly et al. 2002; Meinzer 2003; Shipley and Almeida-Cortez 2003; Burns 2004; Hoffmann et al. 2005). In turn, such trait filtering leads to the expectation that communities will be phylogenetically clustered along gradients, since close relatives often share trait values (Webb et al. 2002; Cavender-Bares et al. 2009; Willis et al. 2010).

The expectation of close matching between environmental filters, functional traits, and evolutionary relatedness may not be met, however, when a single trait reflects multiple abiotic factors, such as plant height responding to both light availability and disturbance (McGill et al. 2006); when environmental gradients are not independent of one another, such as correlations among temperature, moisture availability, and fire (Westerling et al. 2006); or when traits are physiologically and/or evolutionarily linked to one another, such as seed mass and seed number (Stearns 1992; Price 1997; Westoby et al. 2002; Vesk and Westoby 2004). Thus, successful interpretation of the environmental filtering of ecological assemblages may depend on understanding the functional, environmental, and phylogenetic relationships among key traits.

One of the most widely studied resource-use traits in plants is specific leaf area (SLA), also known as leaf area/dry mass (Reich et al. 1997; Cornelissen et al. 2003 and references therein). High SLA tends to be associated with high maximal rates of photosynthesis and growth, and thus with high rates of nutrient consumption and leaf turnover. Low SLA tends to reflect the opposing strategy of slow nutrient consumption, low growth rates and slow leaf turnover (Niinemets 2001; Westoby et al. 2002; Wright et al. 2004; Wright et al. 2005; Westoby and Wright 2006; Cornwell and Ackerly 2009; but see Lusk et al. 2010). 
The value of SLA as an indicator of broad resource-use strategies is demonstrated by its negative correlations with water use efficiency, nitrogen per unit leaf mass, photosynthetic capacity, leaf toughness, leaf longevity, leaf dry matter content, and stomatal conductance (Reich et al. 1997; Niinemets 2001; Wright et al. 2002; Reich et al. 2003; Wright et al. 2004; Hoffmann et al. 2005; Wright 80 et al. 2005; Paula and Pausas 2006; Saura Mas et al. 2009). While individuals within species may vary in their SLA (Messier et al. 2010), among-species variation in SLA is generally considerably greater (Cornelissen et al. 2003), especially in heterogeneous environments (Cornwell and Ackerly 2009).

Community assembly along gradients of climatic favourability or soil fertility is expected to be strongly organised by resource-use strategy as measured by SLA. Species expressing higher SLA values should be found at 90 the more favourable ends of these gradients, i.e. in more mesic (abundant rainfall, less extreme temperatures) climates and on more fertile soils (Lamont and Markey 1995; Hopper et al. 1997; Wisheu et al. 2000; Ackerly et al. 2002; Hoffmann et al. 2005; Cornwell and Ackerly 2009).

95 However, these straightforward expectations may be too simplistic if SLA is linked functionally or phylogenetically to other, non-resource traits, or if there is a lack of independence among the environmental gradients selecting for functional traits.

In this article we examined the proposition that the resource-use strategies expressed in chaparral communities, as reflected by the distribution of community-level SLA values along gradients, are shaped not only by climate and soil fertility but also by fire. Chaparral is the Californian term for evergreen shrubland vegetation associated with Mediterranean climates; within these climates it tends to be found on well-drained and nutrient-poor soils such as sandstone and serpentine. Recurrent crown fires are a universal characteristic of chaparral, and chaparral shrubs show alternative strategies for post-fire regeneration (Keeley and Keeley 2000). Obligate resprouters are species that survive fire and re-establish by resprouting from underground roots, rhizomes or aerial buds; obligate seeders are those that are killed by fire and recruit from soil seed banks; and species using both strategies are called 'facultative seeders' (Table 1). These regeneration syndromes are not independent of resource-use strategies. Resprouting, which is favoured by high fire frequency and severity because it permits quick regeneration, comes at 120 the cost of reduced growth because it requires high allocation to below-ground storage. Seeding, which is favoured by lower fire frequency and severity, requires enhanced adaptation to summer drought because of the extremely high mortality at the seedling stage (Keeley and Zedler 1978; Keeley 1981; Keeley et al. 2006; Pausas et al. 2006; Verdú and Pausas 2007). Thus, although SLA is not a fire-adaptive trait per se, fire regimes may affect it indirectly by the post-fire reproductive strategies for which they select (Clarke 2002a; Clarke 2002b; Clarke et al. 130 2005).
An additional link between fire and resource-use strategies lies in the environmental correlations among climate, soils, and fire. Fire regimes are affected by climate both directly (i.e. fire is more frequent where the dry season is longer and more severe) and indirectly through the effects of climate on plant biomass (i.e. fire may be more frequent or severe where productive climates lead to high fuel loads). Fire regimes may also be affected by soils; for example, plant communities on extremely infertile soils such as serpentine may have less frequent and severe fire because of their lower biomass accumulation and discontinuous canopy cover, leading to a higher prevalence of 'seeder' shrub species on these soils (Safford and Harrison 2004).

In the context of Californian chaparral, we asked whether it is reasonable to expect a dependable matching of a single trait such as SLA to individual environmental filters, or whether interaction terms representing the correlations among traits and among filters are required for a correct interpretation of environmental filtering. We tested the following hypotheses: $\left(\mathrm{H}_{1}\right)$ SLA is only affected by climate; $\left(\mathrm{H}_{2}\right)$ SLA is only affected by soil fertility; $\left(\mathrm{H}_{3}\right)$ SLA is only affected by fire frequency; and $\left(\mathrm{H}_{4}\right)$ SLA is affected by an interaction of several or all of these potential environmental filters.

\section{Materials and methods}

\section{Study system}

We examined 115 plots of chaparral community composition (Figure 1). The plots are from two datasets, referred to as 'McLaughlin' and 'Central Coast'. The McLaughlin plots were sampled on two soils (sandstone and serpentine) and two fire histories (recently burned and unburned); the Central Coast plots were sampled on one soil (sandstone) in two climatic zones (maritime and interior).

The McLaughlin plot data were collected at McLaughlin University of California Reserve, located in Napa, Lake, and Yolo counties, California, USA. The McLaughlin dataset includes 80 plots, each $50 \mathrm{~m} \times 5 \mathrm{~m}$, from two soil types: serpentine $(n=40)$ and sandstone $(n=40)$ (Safford and Harrison 2004). Half of the plots on each soil type burned in an arson fire on 16 October 1999, removing an average of $85 \%$ of the original shrub cover; half of the plots did not burn. We refer to these plots as 'recently burned' and 'unburned', respectively.

At McLaughlin, soil fertility is correlated with fire frequency and intensity, where chaparral on relatively fertile sandstone burns significantly more often than chaparral on very infertile serpentine (time since fire $18.6 \pm 3.1$ years on sandstone vs. $73.7 \pm 39$ years for serpentine) and with higher severity (Safford and Harrison 2004). Fire is less frequent and severe on serpentine because soil infertility limits biomass accumulation, as shown by positive severity-biomass correlations within soil types. Given their proximity, the plots at McLaughlin do not differ in climate.

The Central Coast data include 35 sandstone plots in the coastal ranges of California, spanning climatic zones 
Table 1. Expected characteristics of chaparral species with regard to post-fire regeneration strategy.

\begin{tabular}{|c|c|c|c|}
\hline \multirow[b]{2}{*}{ Characteristic } & \multicolumn{3}{|r|}{ Post fire regeneration strategy } \\
\hline & Resprouter & Seeder & References \\
\hline \multicolumn{4}{|l|}{ Plant level } \\
\hline $\begin{array}{l}\text { Allocation to } \\
\text { storage }\end{array}$ & High & Low & $\begin{array}{l}\text { (Pate et al. 1990; Bell et al. 1996; Bell 2001; Langley et al. 2002; } \\
\text { Knox and Clarke 2005; but see Chew and Bonser 2009) }\end{array}$ \\
\hline Growth rate & Low & High & $\begin{array}{l}\text { (Pate et al. 1990; Bell et al. 1996; Bell 2001; Bond and Midgley } \\
\text { 2003; Schwilk and Ackerly 2005; but see Chew and Bonser } \\
\text { 2009) }\end{array}$ \\
\hline Height & Uncertain & Uncertain & $\begin{array}{l}\text { (Midgley 1996; Bond and Midgley 2003; Falster and Westoby } \\
\text { 2005; Menges 2007) }\end{array}$ \\
\hline Rooting depth & Deep & Shallow & (Bell et al. 1996; Bell 2001) \\
\hline Fecundity & Low & High & $\begin{array}{l}\text { (Lamont 1985; Verdú 2000; Bell 2001; Bond and Midgley 2001; } \\
\text { Lamont and Wiens 2003) }\end{array}$ \\
\hline \multicolumn{4}{|l|}{ Ecological strategy } \\
\hline Fire & Tolerate & Avoid & $\begin{array}{l}\text { (Odion and Davis 2000; Clarke 2002a; Clarke 2002b; Clarke and } \\
\text { Knox 2002; Russell-Smith et al. 2003; Pausas et al. 2004; } \\
\text { Clarke et al. 2005; Franklin et al. 2005; Ojeda et al. 2005; } \\
\text { Keeley et al. 2006) }\end{array}$ \\
\hline Drought/Aridity & Avoid & Tolerate & $\begin{array}{l}\text { (but see Lamont and Markey 1995; Pausas et al. 2004; Clarke } \\
\text { et al. 2005; Lloret et al. 2005; Ojeda et al. 2005; Pratt et al. } \\
\text { 2008; Saura Mas et al. 2009) }\end{array}$ \\
\hline Soil infertility & Avoid & Tolerate & $\begin{array}{l}\text { (Lamont and Markey 1995; Wisheu et al. 2000; Safford and } \\
\text { Harrison 2004) }\end{array}$ \\
\hline Shading & Tolerate & Avoid & (Hawkes and Menges 1996; Menges 2007; Pratt et al. 2008) \\
\hline Lifespan & Long & Short & $\begin{array}{l}\text { (Bond and Midgley 2003; Lamont and Wiens 2003; Chew and } \\
\text { Bonser 2009) }\end{array}$ \\
\hline $\begin{array}{l}\text { Competitive } \\
\text { ability }\end{array}$ & Uncertain & Uncertain & $\begin{array}{l}\text { (Schmalzer 2003; Clarke et al. 2005; Schwilk and Ackerly 2005; } \\
\text { Chew and Bonser 2009; Clarke and Knox 2009) } \\
\text { Schmalzer 2003; Clarke et al. 2005; Schwilk and Ackerly 2005; } \\
\text { Chew and Bonser 2009; Clarke and Knox } 2009\end{array}$ \\
\hline
\end{tabular}

from maritime $(n=17)$ to interior $(n=18)$ (Figure 1$)$. This climate transition integrates decreased presence of a summer marine fog layer, increased temperatures, decreased relative humidity, and decreased summer water availability. Field data from the 35 chaparral plots in summer 2009 showed large differences between maritime and interior (respectively) climate zones in daily average daily leaf wetness $(50.2 \pm 1.9$ vs. $3.8 \pm 0.7 \%)$, vapour pressure difference $(3.3 \pm 0.3$ vs. $21.4 \pm 0.9 \mathrm{kPa})$, average daily maximum temperature $\left(20.0 \pm 0.4\right.$ vs. $\left.31.8 \pm 0.4{ }^{\circ} \mathrm{C}\right)$, and average daily soil water concentration (12.3 \pm 0.1 vs. $2.3 \pm 0.2 \%$ ) (means \pm one standard deviation; Vasey et al., in review).

Fire occurs less frequently in the maritime than the interior climatic zone due to a shorter fire season, associated with cooler, less seasonal temperatures, higher relative humidity, lower evapotranspiration, and higher rainfall (Odion and Tyler 2002). However, chaparral in the maritime climatic zone is found on infertile, shallow, and sandy soils relative to chaparral in the interior climatic zone, because these edaphic factors favour the persistence of chaparral vegetation (Griffin 1978; Sawyer et al. 2009).

\section{Plant community composition and soil variables}

210 At McLaughlin, woody plant community composition and cover was measured in 2002. Visual cover was estimated as a measure of species abundances for species in each of five $1 \mathrm{~m}^{2}$ quadrats spaced evenly along the centre-line of each plot. Cover values were then averaged for each species and each plot. For each plot, $50 \mathrm{~g}$ of soil were collected from the centre of each quadrat at $5-10 \mathrm{~cm}$ depth, mixed, and then analysed by A \& L Western Agricultural Laboratories, Modesto, California, USA, for organic matter, $\mathrm{K}, \mathrm{Mg}, \mathrm{Ca}$, and Bray $\mathrm{P}$.

At the Central Coast plots, the plant composition and cover of woody plants for each of the 35 plots, each $50 \times 20 \mathrm{~m}$, was surveyed between 2003 and 2004 (Vasey et al., in review). Visual cover was estimated in 10 quadrats, each $10 \times 10 \mathrm{~m}$, to provide a mean abundance per species, per plot. Soil was collected from each quadrat at 5-10 cm depth, mixed together, and analysed by Brookside Laboratories, New Knoxville, Ohio, USA, for organic matter, $\mathrm{K}, \mathrm{Mg}, \mathrm{Ca}$, and Bray $\mathrm{P}$.

\section{Climate and fire variables}

To obtain climate data for each Central Coast plot, we intersected plot locations with maps of 10 macroclimate variables from the climate mapping system for the United States PRISM (http://www.prism.oregonstate.edu/). Variables were based on 30-year averages and had a resolution of $1 \mathrm{~km}^{2}$. Variables were relative humidity (\%), potential evapotranspiration $(\mathrm{cm})$, annual temperature $\left({ }^{\circ} \mathrm{C}\right)$, 


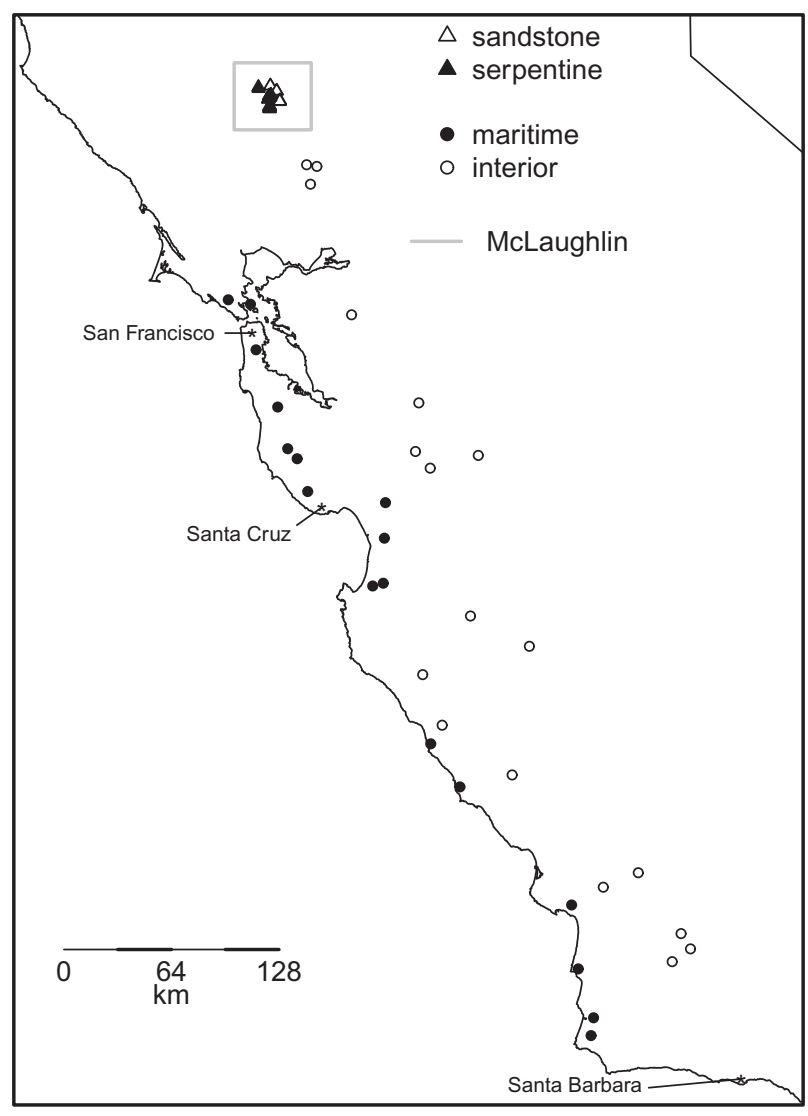

Figure 1. Locations of 115 chaparral study plots in western California. 80 plots were surveyed at McLaughlin, a University of California Natural Reserve, stratified by soil type (sandstone and serpentine) and burn history (recently burned and unburned). In addition, 35 plots were surveyed on sandstone soils in the Central Coast region; these plots were stratified by climatic zone (maritime and interior).

minimum winter temperature $\left({ }^{\circ} \mathrm{C}\right)$, maximum summer temperature $\left({ }^{\circ} \mathrm{C}\right)$, temperature seasonality (standard deviation), annual precipitation, winter precipitation, summer precipitation, and precipitation seasonality (coefficient of variation).

To obtain data on fire regimes, we intersected plot locations with raster grids $\left(250 \mathrm{~m}^{2}\right)$ of 'fuel rank' and 'fire rotation' from the California Department of Forestry and Fire Protection's Fire and Resource Assessment Program (CDF 2003, Fire Regime and Condition Class, Edition 03_2; http://frap.cdf.ca.gov/data/frapgisdata/select. asp?theme=5). Fuel rank is based on topography, vegetative fuel loads, and climate, and varied from -1 for 'little or no fire hazard' to 3 for "very high fire hazard". The fire rotation data are also given in classes, and are based on annual acres burned, vegetation type, development status, elevation, and the bioregion; values range from 1 for 'moderate frequency' to 3 for 'high frequency'.

\section{Trait data - SLA and post-fire regeneration strategy}

Mean SLA $\left(\mathrm{mm}^{2} \mathrm{mg}^{-1}\right)$ was obtained for the 87 species found in the plots (see Table 1 in Appendix 1) from several sources, primarily from new field measurements.
For 66 of the species, SLA was measured from new field collections, where 10 leaves were collected from each of 10 individuals. Individuals were sampled from at least three unique populations. To account for phenotypic plasticity of SLA with respect to soil, for species occurring on both serpentine and non-serpentine (34 of the 66 species), five individuals were sampled from each soil; for the others, all individuals were sampled from one soil type. Mean SLA per species was determined using a standard protocol (Cornelissen et al. 2003). For nine species, SLA data were available from The Ecological Flora of California (http://ucjeps.berkeley.edu/efc/), so new field measurements were not sought. For an additional 12 Arctostaphylos that were very geographically rare, we measured SLA using our own dried herbarium specimens. To validate using SLA from dried leaves versus fresh leaves for Arctostaphylos, we measured SLA from both dry leaves and from fresh leaves for 20 additional, more common Arctostaphylos taxa, and found that the two measures were highly correlated $\left(r^{2}=0.88, n=20, b=1.01\right.$, intercept $=-0.09, P<0.001)$. To examine intraspecific variation of SLA by soil type, soil type-specific SLA means were also calculated for the 34 species collected on two soils. In all analyses described below, mean SLA was log-transformed to meet the assumptions of parametric analyses. It is possible that the SLA values we determined for these species would differ if measured in other environments than those selected because genotypes and environments interact to determine phenotypes.

For each of the 87 species, we determined post-fire regeneration strategy using Hickman (1993), published literature, and expert opinion by the authors (primarily JK). We designated each species as an obligate resprouter, obligate seeder, or facultative resprouter (can resprout or recruit from seed following fire). Only $20 \%$ of our species can both resprout and post-fire seed, suggesting a negative tradeoff between resprouting capacity and propagule persistence (Pausas 2001; Pausas and Verdu 2005).

\section{Analyses}

Correlated environmental filters. We tested if fieldmeasured edaphic variables, remotely sensed macroclimate variables, and/or remotely sensed fire attributes differed among climatic zones (interior, maritime) using one-way ANOVA. Relationships of soil fertility, fire frequency and intensity, and recent burn history at McLaughlin, described above, are reported elsewhere (Safford and Harrison 2004), and thus new analyses were not conducted here.

Correlated traits. At the species level $(n=87)$, we tested whether SLA differed by post-fire regeneration strategy, using one-way ANOVA, and also repeated this analysis using a correction for phylogenetic non-independence (comparative analysis by independent contrasts (CAIC); details in Appendix 2).

The percentage of obligate seeders in each plot was calculated; percentages were weighted by abundance to 
down-weight the relative influence of rare species on the description of functional structure. The abundanceweighted percentage for each plot was calculated as follows: (sum abundance obligate seeders / sum abundance of all species) $\times 100$. We calculated community-level postfire strategy with obligate seeders as the numerator because both facultative resprouters and obligate resprouters are ecologically similar in the sense that they can both resprout. For McLaughlin, we tested if the percentage of obligate seeders differed by soil type, burn history, and their interaction (two-way ANOVA). Prior to analysis, the percentage of obligate seeders was arc-sine transformed. For the Central Coast dataset, we tested if the percentage of seeders differed among climatic zones using one-way ANOVA.

Environmental correlates of SLA. At the community level, we tested if the mean abundance-weighted SLA observed in each plot at McLaughlin differed by soil type, burn history, and their interaction (two-way ANOVA). For each plot, the mean abundance-weighted SLA was calculated by summing the product of each species' SLA and its proportion of total cover in that plot, and then dividing by the number of species in that plot. We used the proportion of a species cover in each plot as our metric of abundance, rather than abundance alone. To examine for intraspecific variation in SLA by soil type, we compared the SLA of sandstone collections with the SLA of serpentine collections for the 34 species collected from both soil types using a paired $t$-test. For the Central Coast, we tested if abundanceweighted mean SLA differed among climatic zones using one-way ANOVA.

Environmental filtering of SLA. To test for filtering of SLA, the range of SLA for each community was calculated (range $\left.{ }_{\text {obs }}\right)$ and compared with a null expectation of the range of SLA at the observed level of richness (range exp $_{\text {) }}$ (sensu Cornwell and Ackerly 2009). We randomly sampled the species pool, by data set, 9999 times for each level of observed species richness among the plots, and calculated the mean range of SLA values for each level of species richness. Communities in which a filter is operating

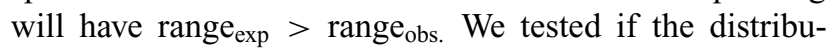
tion of range $e_{\exp }-$ range $_{\text {obs }}$ was significantly greater than zero using a one-tailed $t$-test. We then tested if range exp $_{-}$ range $_{\text {obs }}$ in each plot differed by soil type, burn history, and climatic zone using a two-way ANOVA. All analyses were performed in $\mathrm{R}$ version 12.0 ( $\mathrm{R}$ Development Core Team 2010).

\section{Results}

\section{Correlated environmental filters}

Serpentine plots had a significantly lower $\mathrm{Ca}: \mathrm{Mg}$ ratio, higher organic matter content, and lower $\mathrm{P}$ and $\mathrm{K}$ levels than the sandstone plots. The less fertile maritime plots also had a significantly lower $\mathrm{Ca}: \mathrm{Mg}$ ratio and lower $\mathrm{P}$ level than the interior plots (Table 2). There were higher fuel levels and also more frequent fires in interior plots than in maritime plots (Table 2). For the macroclimate variables, interior plots were shown to be significantly more arid than maritime plots (lower relative humidity, higher potential evapotranspiration, higher summer temperature, lower winter temperature, and higher temperature seasonality), although precipitation did not differ by zone (Table 2 in Appendix 1).

\section{Correlated traits}

At the species level, mean SLA was significantly higher in obligate resprouters than in either facultative resprouters or obligate seeders (one-way ANOVA: $F_{2,84}=16.4$; $P<0.001$ ) (Figure 2). This relationship was not significant after correction for phylogenetic non-independence $(P=0.327)$ (Appendix 2), demonstrating shared variation among higher taxa.

The abundance-weighted percentage of seeders was significantly lower on sandstone soils compared to serpentine soils (Figure 3a), but this soil contrast disappeared in recently burned plots (two-way ANOVA: soil $F_{1,76}=$ 26.2, $P<0.001$; burn history $F_{1,76}=21.9, P<0.001$; soil $\times$ burn history $F_{1,76}=2.94, P=0.09$; Figure 3a). For the Central Coast plots, there was a higher abundanceweighted percentage of obligate seeders in the low-fire, maritime climatic zone compared with the high-fire, interior climatic zone (Table 2; Figure 3c). The Central Coast compared with McLaughlin had fewer obligate resprouters ( 0.40 vs. 0.54$)$, more obligate seeders ( 0.38 vs. 0.27$)$, and roughly the same proportion of facultative seeders (0.22 vs. 0.19$)$.

\section{Environmental correlates of specific leaf area}

In the McLaughlin plots, abundance-weighted mean SLA was significantly higher on sandstone soils compared with serpentine soils (Figure 3b), regardless of burn history (two-way ANOVA: soil $F_{1,76}=20.3, P<0.001$; burn history $F_{1,76}=1.0, P=0.31$; soil $\times$ burn history $F_{1,76}=0.3$, $P=0.59$ ). Abundances were significantly lower on serpentine soils, but this difference was only present among the unburned plots (Figure 3c; two-way ANOVA: soil $F_{1,76}=$ $6.1, P=0.015$; burn history $F_{1,76}=690.5, P<0.001$; soil $\times$ burn history $\left.F_{1,76}=4.9, P=0.03\right)$. In the Central Coast plots, abundance-weighted mean SLA was not significantly different between climatic zones (Figure 3e), nor was abundance (Figure 3f).

Conspecifics had $18 \%$ higher mean SLA on sandstone than serpentine soil (paired $t$-test: $t=2.31, d f=33$, $P=0.027$ ). At the community level, in contrast, mean unweighted SLA was even greater, with values in sandstone plots $32 \%$ higher than in serpentine. Thus, variation in SLA among communities was due to both compositional turnover and intraspecific variation (i.e. phenotypic plasticity), but species replacement played a larger role, similar to previous results for Californian woody plants (Cornwell and Ackerly 2009).

\section{Environmental filtering of SLA}

The range of SLA values for the McLaughlin plots was significantly lower than expected under the null model, 
Table 2. Environmental differences by soil type (McLaughlin plots; sandstone, serpentine) and climatic zone (Central Coast plots; interior, maritime).

\begin{tabular}{|c|c|c|c|c|c|c|c|c|}
\hline & \multicolumn{4}{|c|}{ McLaughlin } & \multicolumn{4}{|c|}{ Central Coast } \\
\hline & Sandstone & Serpentine & $F$ & $P$ & Interior & Maritime & $F$ & $P$ \\
\hline \multicolumn{9}{|l|}{ Edaphic } \\
\hline $\mathrm{Ca}: \mathrm{Mg}$ ratio & $3.4 \pm 2.2$ & $0.5 \pm 0.5$ & 69.1 & $<0.001$ & $6.9 \pm 1.6$ & $4.5 \pm 3.4$ & 7.2 & 0.011 \\
\hline Bray P (ppm) & $7.0 \pm 2.6$ & $3.4 \pm 1.8$ & 53.0 & $<0.001$ & $37.6 \pm 23.6$ & $14.4 \pm 33.5$ & 5.5 & 0.025 \\
\hline $\mathrm{K}(\mathrm{ppm})$ & $227.8 \pm 62.8$ & $128.5 \pm 71.3$ & 44.0 & $<0.001$ & $221.1 \pm 76.7$ & $172.6 \pm 88.6$ & 3.0 & 0.094 \\
\hline $\begin{array}{l}\text { Organic } \\
\text { matter }(\%)\end{array}$ & $4.3 \pm 0.9$ & $5.2 \pm 1.5$ & 9.5 & 0.003 & $5.0 \pm 3.8$ & $6.5 \pm 1.8$ & 2.2 & 0.152 \\
\hline \multicolumn{9}{|l|}{ Fire } \\
\hline Fuel rank ${ }^{1}$ & na & na & na & na & $2.1 \pm 0.5$ & $1.6 \pm 0.7$ & 6.6 & 0.015 \\
\hline Fire rotation & na & na & na & na & $2.6 \pm 0.6$ & $1.5 \pm 1.1$ & 15.3 & 0.001 \\
\hline
\end{tabular}

Notes: Mean \pm one standard deviation. $P$ values are reported from one-way ANOVA of each variable with soil type or climatic zone. Degrees of freedom for McLaughlin are 1 and 78 for the factor and the residuals, respectively. Degrees of freedom for Central Coast are 1 and 33 for the factor and the residuals, respectively.

${ }^{1}$ Higher fuel ranks correspond to higher potential fire hazard.

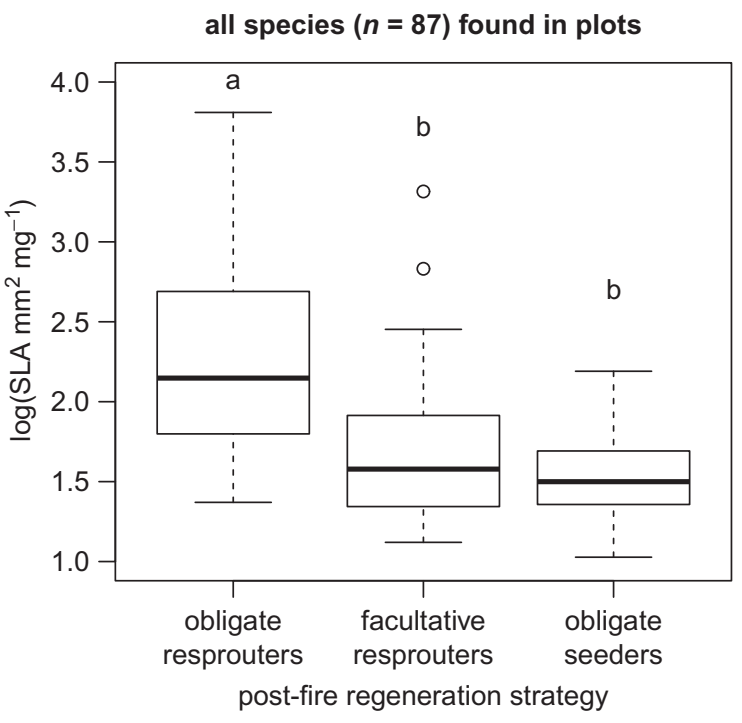

Figure 2. Relationship of SLA and post-fire regeneration strategy among the 87 species considered here. Letters above boxplots indicate significant differences based on a post-hoc Tukey's HSD test. Open circles indicate observations considered to be outliers.

indicating environmental filtering ( 54 of 80 had range exp $_{-}$ range $_{\mathrm{obs}}<0 ; P=0.004$ ) (Figures $4 \mathrm{a}, \mathrm{b}$ ). Filtering strength (range $_{\text {exp }}-$ range $_{\text {obs }}$ ) was significantly higher on sandstone than serpentine (one-way ANOVA: soil $F_{1,78}=15.7, P=$ 0.0002; Table 2). Filtering strength was also related to burn history, and soil type $\times$ burn history (two-way ANOVA: soil $F_{1,76}=18.4, P<0.001$, burn history $F_{1,76}=11.6$, $P=0.001$; soil $\times$ burn history $\left.F_{1,76}=4.2, P=0.044\right)$. The interaction term reflected that filtering was significant for unburned plots on both soils and for recently burned plots on serpentine, but not recently burned plots on sandstone. The range of SLA values for the Central Coast plots was not significantly lower than expected (17 of 35 had range exp $_{-}$ range $_{\mathrm{obs}}<0 ; P=0.378$ ) indicating a lack of filtering by climatic zone (Table 2, Figure 4c).

\section{Discussion}

Among Californian chaparral communities varying in climate, soil fertility, and fire histories, we found that SLA, a critical indicator of resource-use strategy, did not follow the simple patterns anticipated from considering individual filters. Within the McLaughlin data, SLA was lower on infertile serpentine soils, as expected, but fire also played a role in broadening the range of SLA present on more fertile sandstone soils (relaxing filtering). Within the Central Coast data, SLA did not follow any simple expectations, being higher neither in more equable maritime climates, nor in the interior where soils are more fertile and fires are more frequent. These results are most consistent with the hypothesis that SLA is affected by an interaction of climate, soil fertility, and fire. Key to understanding this interaction are the correlations we found, at both the species and community levels, between SLA and post-fire regeneration strategies, and also the environmental correlations between climate, soils, and fire frequency.

Obligate post-fire seeders had significantly lower SLA than obligate post-fire resprouters (Figure 2). This contradicts the notion that the reduced need for storage of the seeding strategy should lead to relatively higher growth rates and associated higher SLA in seeders (Table 1). The correlation we observed may reflect a physiological tradeoff in which obligate seeding imposes strong selection for drought tolerance at the seedling stage (Ackerly 2004). Infertile soils may also select for drought-tolerant seeders due to imposing arid conditions (high rock content, high exposure to direct sun, high rates of soil evaporation) (Ojeda et al. 2005; Pratt et al. 2008). While seeders have low allocation to roots and shallow rooting depth, and thus a limited ability to avoid drought by reaching water in lower soil horizons, they may tolerate soil aridity if they have leaflevel strategies, such as low SLA, that provide an advantage under low-resource conditions (Poorter et al. 2009; Saura Mas et al. 2009). Post-fire resprouters, in contrast, avoid drought by having deeper rooting systems (Bell et al. 1996; Bell 2001). 
McLaughlin

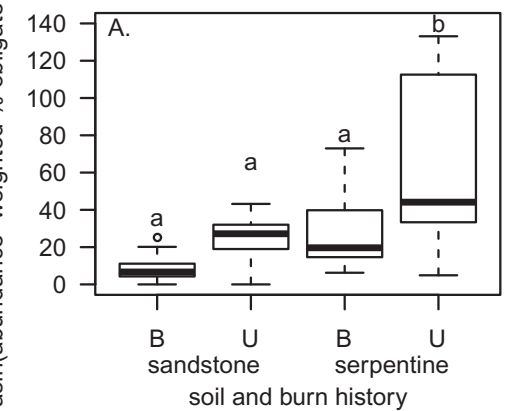

Central Coast

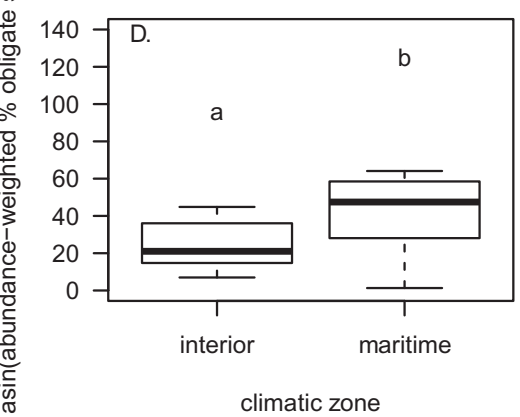

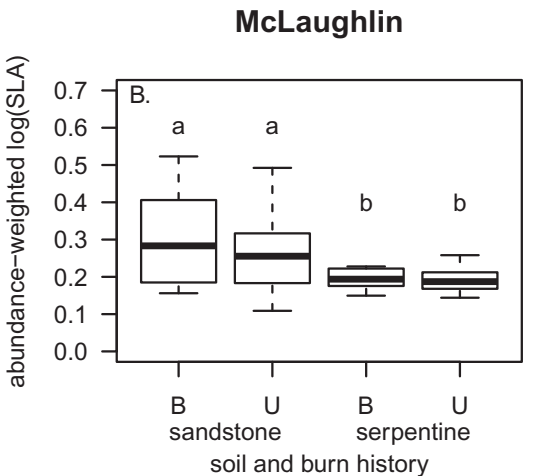

Central Coast

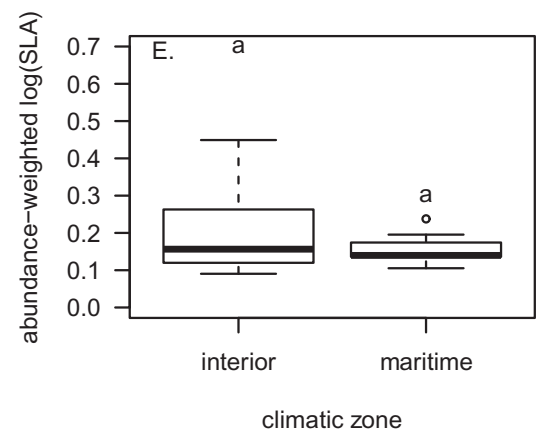

McLaughlin

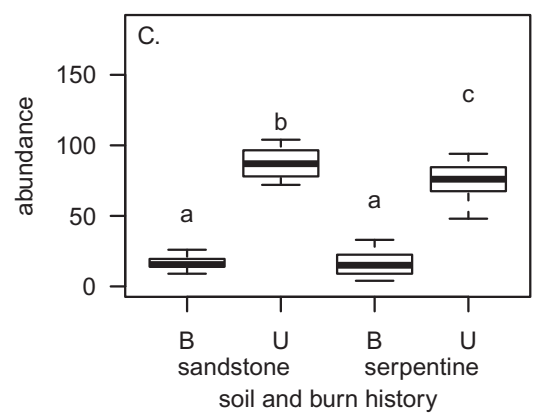

Central Coast

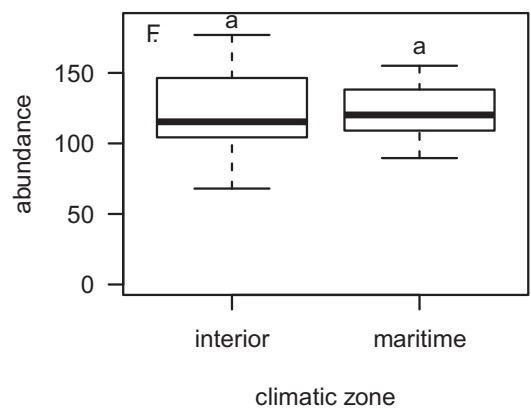

Figure 3. Plant community attributes for serpentine and sandstone soils $(\mathrm{a}-\mathrm{c})$ and interior and maritime climatic zones $(\mathrm{d}-\mathrm{f})$. Recent fire history is indicated for the McLaughlin data as follows: $\mathrm{B}=$ recently burned, $\mathrm{U}=$ unburned. Letters above boxplots indicate significant differences based on a post-hoc Tukey's HSD test. Open circles indicate observations considered to be outliers.

The correlation between post-fire regeneration strategy and SLA was not significant in an analysis of phylogenetically independent contrasts, reflecting the influence of species-rich lineages (i.e. Arctostaphylos and Ceanothus; Appendices 1 and 2) that share particular trait combinations (e.g. post-fire seeding and low SLA) through common inheritance. This means that the observation of low SLA and obligate seeding in a community is in part due to common descent. In other words, an environmental filter may be directly selecting for obligate seeding, and thereby indirectly selecting for the correlated low SLA value, or vice versa. Similarly, a study of 37 plants of the 490 Iberian peninsula showed phylogenetic non-independence among post-fire regeneration strategy and fruit type (Pausas and Verdu 2005). Such patterns of phylogenetic nonindependence in traits are well known and form the basis of phylogenetic clustering in community structure (Webb et al. 2002; Anacker 2011).

The observed patterns of post-fire regeneration strategy confirmed that fire was more frequent on sandstone relative to serpentine (obligate seeders were more common in serpentine chaparral), and that fire was more frequent in the interior than on the coast (obligate seeders more common in maritime chaparral). In the arid interior, the infertile conditions of serpentine soil limit fuel accumulation, creating local fire refugia and favouring seeders. Along the coast, cool and wet climates limit the length and severity of the fire season and the flammability of fuels, leading to low regional fire frequencies, favouring seeders; low soil fertility is likely important in determining the balance between woodland and chaparral (Griffin 1978; Sawyer et al. 2009), rather than affecting fire regime. Another factor favouring obligate seeding in maritime chaparral is that longer time intervals between fires may increase the severity of fires when they do occur, lowering adult survivorship.

Chaparral on serpentine soils at McLaughlin had significantly lower SLA than chaparral on sandstone even immediately following a fire (Figure 3), suggesting that soils play the dominant role in shaping SLA in this setting. However, our observation that low-SLA obligate seeders are much more prevalent on infrequently burning serpentine stands (Figure 3) suggests that fire does interact with soil to determine community-level SLA over longer time periods. In our Central Coast data, SLA did not differ between maritime and interior plots, even though mesic maritime climates should promote high SLA near the coast, while both frequent fire and more fertile soils are predicted to lead to higher SLA in the interior. Abundant evidence from other studies shows that SLA tends to be higher in productive habitats (reviewed in Cornelissen et al. 2003; Westoby and Wright 2006; Poorter et al. 2009), such as our maritime plots where water availability is high. Thus, one of our more striking findings is that the globally predominant role of climate in shaping SLA can be nullified by the 

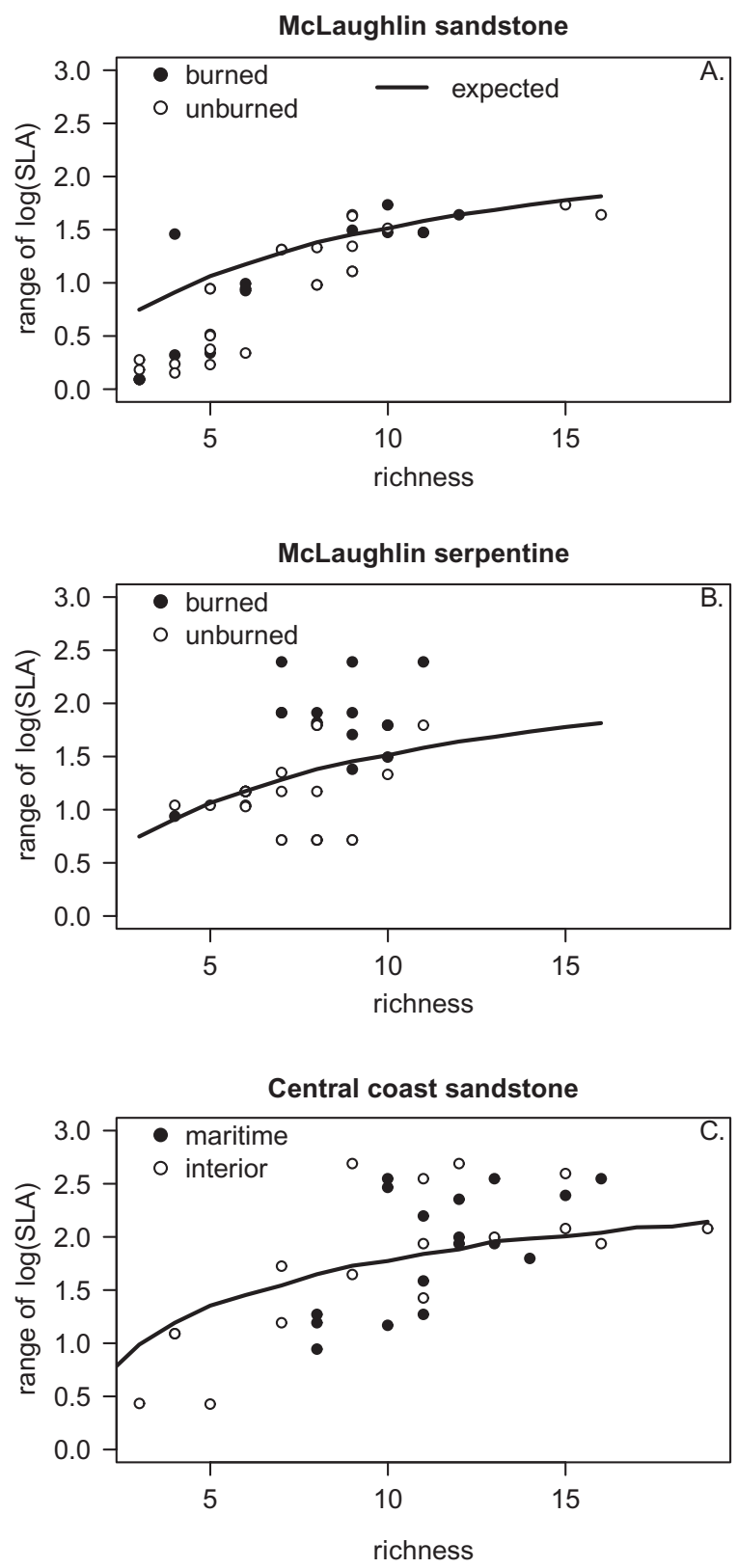

Figure 4. The range of SLA observed in chaparral plots versus null expectation. Points below the line have lower observed ranges than expected by chance.

more localised effects of soil fertility and fire, if these gradients happen to vary in the opposite direction with respect to their effects on SLA.

\section{Conclusions}

We found that community structure in Californian chaparral is shaped by the environmental filtering of a key resource-acquisition trait - SLA - by the simultaneous effects of climate, soil fertility, and fire. Interactive effects of these three filters arose from two factors: the phylogenetic and functional non-independence of SLA and another critical trait (post-fire regeneration strategy), and the non-independence of the three environmental filters themselves. Our results provide a clear warning that incorrect inferences about functional and phylogenetic community structure may be reached when either traits or filters are considered in isolation.

\section{Notes on contributors}

\section{References}

Ackerly DD. 2004. Functional strategies of chaparral shrubs in relation to seasonal water deficit and disturbance. Ecological Monographs 74:25-44.

Ackerly D, Knight C, Weiss S, Barton K, Starmer K. 2002. Leaf size, specific leaf area and microhabitat distribution of chaparral woody plants: contrasting patterns in species level and community level analyses. Oecologia 130:449-457.

Anacker BL. 2011. Phylogenetic patterns of serpentine plant endemism and diversity. In: Harrison SP, Rajakaruna N, editors. Serpentine as a Model in Evolution and Ecology. Berkeley, California, USA:University of California Press. p. 49-70.

Bell DT. 2001. Ecological response syndromes in the flora of southwestern Western Australia: fire resprouters versus reseeders. The Botanical Review 67:417-440.

Bell TL, Pate JS, Dixon KW. 1996. Relationships between fire response, morphology, root anatomy and starch distribution in south-west Australian Epacridaceae. Annals of Botany 77:357.

Bond WJ, Midgley JJ. 2001. The persistence niche: ecology of sprouting in woody plants. Trends in Ecology and Evolution $16: 45-51$.

Bond WJ, Midgley JJ. 2003. The evolutionary ecology of sprouting in woody plants. International Journal of Plant Sciences 164:103-114.

Burns K. 2004. Patterns in specific leaf area and the structure of a temperate heath community. Diversity and Distributions 10:105-112.

Cavender-Bares J, Kozak KH, Fine PVA, Kembel SW. 2009. The merging of community ecology and phylogenetic biology. Ecology Letters 12:693-715.

Chew SJ, Bonser SP. 2009. The evolution of growth rate, resource allocation and competitive ability in seeder and resprouter tree seedlings. Evolutionary Ecology 23:723-735.

Clarke PJ. 2002a. Habitat insularity and fire response traits: evidence from a sclerophyll archipelago. Oecologia 132:582-591.

Clarke PJ. 2002b. Habitat islands in fire-prone vegetation: do landscape features influence community composition? Journal of Biogeography 29:677-684.

Clarke PJ, Knox KJE. 2002. Post-fire response of shrubs in the tablelands of eastern Australia: do existing models explain habitat differences? Australian Journal of Botany 50:53-62.

Clarke PJ, Knox KJE. 2009. Trade offs in resource allocation that favour resprouting affect the competitive ability of woody seedlings in grassy communities. Journal of Ecology 97:1374-1382.

Clarke PJ, Knox KJE, Wills KE, Campbell M. 2005. Landscape patterns of woody plant response to crown fire: disturbance and productivity influence sprouting ability. Ecology 93:544-555.

Cornelissen JHC, Lavorel S, Garnier E, Diaz S, Buchmann N, Gurvich DE, Reich PB, Steege H, Morgan HD, Heijden MGA. 2003. A handbook of protocols for standardised and easy measurement of plant functional traits worldwide. Australian Journal of Botany 51:335-380.

\section{5}

. 
Cornwell WK, Ackerly DD. 2009. Community assembly and shifts in plant trait distributions across an environmental gradient in coastal California. Ecological Monographs 79:109-126.

Diamond JM. 1975. Assembly of species communities. In: Cody ML, Diamond JM, editors. Ecology and evolution of communities. Cambridge, MA, USA:Harvard University Press. p. $342-444$

Diaz S, Cabido M, Casanoves F. 1998. Plant functional traits and environmental filters at a regional scale. Journal of Vegetation Science 9:113-122.

Falster DS, Westoby M. 2005. Tradeoffs between height growth rate, stem persistence and maximum height among plant species in a post fire succession. Oikos 111:57-66.

Franklin J, Syphard AD, He HS, Mladenoff DJ. 2005. Altered fire regimes affect landscape patterns of plant succession in the foothills and mountains of southern California. Ecosystems $8: 885-898$

Griffin JR. 1978. Maritime chaparral and endemic shrubs of the Monterey Bay region, California. Madrono 25:65-81.

Grime JP. 1979. Plant strategies and vegetation processes. Chichester, UK:John Wiley \& Sons Ltd.

Grubb PJ. 1977. The maintenance of species-richness in plant communities: the importance of the regeneration niche. Biological Reviews 52:107-145.

Hawkes CV, Menges ES. 1996. The relationship between open space and fire for species in a xeric Florida shrubland. Bulletin of the Torrey Botanical Club 123:81-92.

Hickman JC, editor. 1993. The Jepson Manual. Higher Plants of California. Berkeley, California, USA:University of California Press.

Hoffmann WA, Franco AC, Moreira MZ, Haridasan M. 2005. Specific leaf area explains differences in leaf traits between congeneric savanna and forest trees. Functional Ecology 19:932-940.

Hopper SD, Brown AP, Marchant NG. 1997. Plants of Western Australian granite outcrops. Journal of the Royal Society of Western Australia 80:141-158.

Keeley JE. 1981. Reproductive cycles and fire regimes. In: Proceedings of the Conference, Fire Regimes and Ecosystem Properties, vol. General Technical Report WO-26. USDA Forest Service. p. 231-277.

Keeley JE, Fotheringham CJ, Baer-Keeley M. 2006. Demographic patterns of postfire regeneration in Mediterraneanclimate shrublands of California. Ecological Monographs 76:235-255.

Keeley JE, Keeley SC. 2000. Chaparral. North American terrestrial vegetation $2: 204-253$.

Keeley JE, Zedler PH. 1978. Reproduction of chaparral shrubs after fire: a comparison of sprouting and seeding strategies. American Midland Naturalist 99:142-161.

Knops JMH, Reinhart K. 2000. Specific leaf area along a nitrogen fertilization gradient. American Midland Naturalist:265-272.

Knox KJE, Clarke PJ. 2005. Nutrient availability induces contrasting allocation and starch formation in resprouting and obligate seeding shrubs. Functional Ecology 19:690-698.

Lamont BB. 1985. The comparative reproductive biology of three Leucospermum species (Proteaceae) in relation to fire responses and breeding system. Australian Journal of Botany 33:139-145.

Lamont BB, Markey A. 1995. Biogeography of fire-killed and resprouting Banksia species in south-western Australia. Australian Journal of Botany 43:283-303.

Lamont BB, Wiens D. 2003. Are seed set and speciation rates always low among species that resprout after fire, and why? Evolutionary Ecology 17:277-292.

Langley J, Drake B, Hungate B. 2002. Extensive belowground carbon storage supports roots and mycorrhizae in regenerating scrub oaks. Oecologia 131:542-548.
Lloret F, Estevan H, Vayreda J, Terradas J. 2005. Fire regenerative syndromes of forest woody species across fire and climatic gradients. Oecologia 146:461-468.

Lusk C, Onoda Y, Kooyman R, Gutierrez Girun A. 2010. Reconciling species level vs. plastic responses of evergreen leaf structure to light gradients: shade leaves punch above their weight. New Phytologist 186:429-438.

McGill BJ, Enquist BJ, Weiher E, Westoby M. 2006. Rebuilding community ecology from functional traits. Trends in Ecology \& Evolution 21:178-185.

Meinzer FC. 2003. Functional convergence in plant responses to the environment. Oecologia 134:1-11.

Menges ES. 2007. Integrating demography and fire management: an example from Florida scrub. Australian Journal of Botany $55: 261-272$

Messier J, McGill BJ, Lechowicz MJ. 2010. How do traits vary across ecological scales? A case for trait based ecology. Ecology Letters 13:838-848.

Midgley JJ. 1996. Why the world's vegetation is not totally dominated by resprouting plants; because resprouters are shorter than reseeders. Ecography 19:92-95.

Niinemets U. 2001. Global-scale climatic controls of leaf dry mass per area, density, and thickness in trees and shrubs. Ecology $82: 453-469$.

Odion D, Tyler C. 2002. Are long fire-free periods needed to maintain the endangered, fire-recruiting shrub Arctostaphylos morroensis (Ericaceae)? Conservation Ecology 6:4.

Odion DC, Davis FW. 2000. Fire, soil heating, and the formation of vegetation patterns in chaparral. Ecological Monographs 70:149-169.

Ojeda F, Brun FG, Vergara JJ. 2005. Fire, rain and the selection of seeder and resprouter life-histories in fire-recruiting, woody plants. New Phytologist:155-165.

Pate JS, Froend RH, Bown BJ, Hansen A, Kuo J. 1990. Seedling growth and storage characteristics of seeder and resprouter species of Mediterranean-type ecosystems of SW Australia. Annals of Botany 65:585.

Paula S, Pausas J. 2006. Leaf traits and resprouting ability in the Mediterranean basin. Functional Ecology 20:941-947.

Pausas J, Verdu M. 2005. Plant persistence traits in fireprone ecosystems of the Mediterranean basin: a phylogenetic approach. Oikos 109:196-202.

Pausas JG. 2001. Resprouting vs. seeding - a Mediterranean perspective. Oikos 94:193-194

Pausas JG, Bradstock RA, Keith DA, Keeley JE. 2004. Plant functional traits in relation to fire in crown-fire ecosystems. Ecology 85:1085-1100.

Pausas JG, Keeley JE, VerdÚ M. 2006. Inferring differential evolutionary processes of plant persistence traits in Northern Hemisphere Mediterranean fire-prone ecosystems. Ecology 94:31-39.

Poorter H, Niinemets, Poorter L, Wright IJ, Villar R. 2009. Causes and consequences of variation in leaf mass per area (LMA): a meta analysis. New Phytologist 182:565-588.

Pratt RB, Jacobsen AL, Mohla R, Ewers FW, Davis SD. 2008. Linkage between water stress tolerance and life history type in seedlings of nine chaparral species (Rhamnaceae). Journal of Ecology 96:1252-1265.

Price T. 1997. Correlated evolution and independent contrasts. Transactions of the Royal Society B: Biological Sciences 352:519-529.

Reich PB, Walters MB, Ellsworth DS. 1997. From tropics to tundra: global convergence in plant functioning. Proceedings of the National Academy of Sciences of the United States of America 94:13730.

Reich PB, Wright IJ, Cavender-Bares J, Craine JM, Oleksyn J, Westoby M, Walters MB. 2003. The evolution of plant functional variation: traits, spectra, and strategies. International Journal of Plant Sciences 164:143-164. 
Russell-Smith J, Whitehead P, Cook G, Hoare J. 2003. Response of Eucalyptus-dominated savanna to frequent fires: lessons from Munmarlary, 1973-1996. Ecological Monographs 73:349-375

Safford HD, Harrison SP. 2004. Fire effects on plant diversity in serpentine vs. sandstone chaparral. Ecology 85:539-548.

Saura Mas S, Shipley B, Lloret F. 2009. Relationship between post fire regeneration and leaf economics spectrum in Mediterranean woody species. Functional Ecology 23:103-110.

Sawyer J, Keeler-Wolf T, Evans J. 2009. A Manual of California Vegetation, Second Edition. Sacramento, CA, USA:California Native Plant Society.

Schmalzer PA. 2003. Growth and recovery of oak-saw palmetto scrub through ten years after fire. Natural Areas Journal 23:5-13.

Schwilk DW, Ackerly DD. 2005. Is there a cost to resprouting? Seedling growth rate and drought tolerance in sprouting and nonsprouting Ceanothus (Rhamnaceae) 1. American Journal of Botany 92:404-410.

Shipley B, Almeida-Cortez J. 2003. Interspecific consistency and intraspecific variability of specific leaf area with respect to irradiance and nutrient availability. Ecoscience 10: 74-79.

Stearns S. 1992. The evolution of life histories. Oxford, UK:Oxford University Press.

Verdú M. 2000. Ecological and evolutionary differences between Mediterranean seeders and resprouters. Journal of Vegetation Science 11:265-268.

Verdú M, Pausas JG. 2007. Fire drives phylogenetic clustering in Mediterranean Basin woody plant communities. Ecology 95:1316-1323.

Vesk PA, Westoby M. 2004. Sprouting ability across diverse disturbances and vegetation types worldwide. Journal of Ecology 92:310-320.
Webb CO, Ackerly DD, McPeek MA, Donoghue MJ. 2002. Phylogenies and community ecology. Annual Review of Ecology and Systematics 33:475-505.

Weiher E, Keddy PA. 2001. Ecological assembly rules: perspectives, advances, retreats. Cambridge, UK:Cambridge University Press.

Westerling AL, Hidalgo HG, Cayan DR, Swetnam TW. 2006. Warming and earlier spring increase western US forest wildfire activity. Science 313:940.

Westoby M, Falster DS, Moles AT, Vesk PA, Wright IJ. 2002. Plant ecological strategies: Some leading dimensions of variation between species. Annual Review of Ecology and Systematics 33:125-159.

Westoby M, Wright IJ. 2006. Land-plant ecology on the basis of functional traits. Trends in Ecology \& Evolution 21:261-268.

Willis CG, Halina M, Lehman C, Reich PB, Keen A, McCarthy S, Cavender-Bares J. 2010. Phylogenetic community structure in Minnesota oak savanna is influenced by spatial extent and environmental variation. Ecography 33:565-577.

Wisheu IC, Rosenzweig ML, Olsvig-Whittaker L, Shmida A. 2000. What makes nutrient-poor Mediterranean heathlands so rich in plant diversity? Evolutionary Ecology Research 2:935-955.

Wright IJ, Reich PB, Cornelissen JHC, Falster DS, Groom PK, Hikosaka K, Lee W, Lusk CH, Niinemets, Oleksyn J. 2005. Modulation of leaf economic traits and trait relationships by climate. Global Ecology and Biogeography 14:411-422.

Wright IJ, Reich PB, Westoby M, Ackerly DD, Baruch Z, Bongers F, Cavender-Bares J, Chapin T, Cornelissen JHC, Diemer M. 2004. The worldwide leaf economics spectrum. Nature 428:821-827.

Wright IJ, Westoby M, Reich PB. 2002. Convergence towards higher leaf mass per area in dry and nutrient poor habitats has different consequences for leaf life span. Journal of Ecology 90:534-543. 